\title{
Diurnal behavior of dairy cows on alfalfa pastures supplemented with corn silage and concentrate
}

\author{
[Comportamento diurno de vacas leiteiras em pastagem de alfafa suplementada com \\ silagem de milho e concentrado] \\ D. Peres Netto ${ }^{1}$, A.R.B. Ribeiro ${ }^{2}$, A.A. Rodrigues ${ }^{3}$, R.P. Ferreira ${ }^{3}$, F.C. Mendonça ${ }^{3}$, \\ A.R. Freitas ${ }^{3}$, M. Campana ${ }^{4}$, F.S. Wechsler ${ }^{4}$ \\ ${ }^{1}$ Universidade Federal de Santa Catarina - Florianópolis, SC \\ ${ }^{2}$ FMU - São Paulo, SP \\ ${ }^{3}$ Embrapa Pecuária Sudeste - São Carlos, SP \\ ${ }^{4}$ Universidade Estadual Paulista "Júlio de Mesquita Filho" - FMVZ-Unesp - Botucatu, SP
}

\begin{abstract}
The diurnal ingestive behavior of dairy cows on alfalfa pastures supplemented with corn silage and concentrate was evaluated. Sixteen Holstein dairy cows in mid-lactation were used in a randomized block design. The treatments were partial replacement of corn silage for limited alfalfa grazing time (LGT) or unlimited grazing time (UGT). Rotational alfalfa grazing was used and the amount of concentrate fed was the same in both treatments. Behavioral activities observed were time spent grazing, rumination and idleness, during four days, from 8:00 AM to 7:00 PM. From 2:00 to 5:00 PM grazing was intermittent and short-lasting on UGT, whereas on LGT grazing activity was longer than UGT in the morning and at the end of the afternoon. Restriction in available grazing time clearly influenced the distribution of time spent with grazing, rumination and idleness throughout the day. However, this effect was not observed in the total time spent in these activities.
\end{abstract}

Keywords: unrestricted grazing, restricted grazing, bite rate

\section{RESUMO}

Avaliou-se o comportamento ingestivo de vacas leiteiras com acesso restrito ou irrestrito a uma pastagem de alfafa suplementada com silagem de milho e concentrado. Utilizaram-se 16 vacas da raça Holandesa, em estádio médio de lactação, em delineamento em blocos ao acaso. Os tratamentos foram: silagem de milho substituída parcialmente por pastejo restrito ou irrestrito de alfafa. As vacas foram manejadas em sistema de pastejo rotacionado e a quantidade de concentrado foi igual em ambos os tratamentos. As atividades comportamentais observadas foram pastejo, ruminação e ócio, das oito às 19 horas, em quatro ocasiões. No pastejo irrestrito, observou-se que, nos horários entre 14 e 17 horas, o pastejo foi intermitente e de curta duração, enquanto no pastejo restrito a atividade de pastejo foi mais prolongada durante a manhã e no final da tarde. A restrição no tempo disponível para pastejo da alfafa influenciou marcadamente a distribuição, no decorrer do dia, do tempo gasto em pastejo, da ruminação e do ócio. Entretanto, não se observou este efeito no tempo total gasto nestas atividades.

Palavras-chave: pastejo irrestrito, pastejo restrito, taxa de bocado

\section{INTRODUCTION}

Average temperatures and the high incidence of solar radiation are classical characteristics that determine seasons in Brazil. These situations, when combined with inappropriate dairy cattle management, can result in thermal stress and cause reproduction problems and alter animal behavior (Sousa Júnior, 2008). Knowledge regarding animal behavior is important because it can help to improve system management (Carvalho and Moraes, 2005) and pasture feeding (Mendonça et al., 2004).

Recebido em 18 de julho de 2012

Aceito em 5 de novembro de 2013

E-mail: dperesnetto@gmail.com.br 
The standard behavior is related with feed, rumination and idleness periods. Grazing is the most important activity in grazing systems. Cows can spend approximately 7 to 10 hours a day grazing (Hodgson, 1990) and it is related to season, forage quality, weather, water source location, age and stage of lactation. According to Vilela et al. (1994), Holstein cow grazing on alfalfa in the southeast of São Paulo state (Brazil) stopped grazing in a very warm time of the day and re-started eating in the end of afternoon and during the night, a total of 8 hours of grazing per day. On another trial with dairy cattle grazing in a rotational alfalfa system, a very intense intake from 3 hours after the morning milking time (Jahn et al., 2000) was observed. The rumination activity took around 4 to 9 hours per day and may depend on the kind of diet (Van Soest, 1994). However, dairy cattle can spend from 8 to 10 hours per day in idleness, the period related to the time without grazing and rumination (Phillips and Rind, 2001).

Several experiments have evaluated bovine grazing behavior, (Gregorini et al., 2007; Moreno et al., 2008; Gregorini et al., 2009a,b), but experiments with dairy cattle grazing alfalfa under different grazing strategies in a tropical zone are scarce. Thus, the goal of this experiment was to evaluate diurnal behavior of dairy cows with limited or unlimited access to alfalfa pastures supplemented with corn silage and concentrate in a tropical zone.

\section{MATERIAL AND METHODS}

The experiment was carried out at Embrapa Pecuária Sudeste farm, located in the city of São Carlos, state of São Paulo, Brazil $\left(21^{\circ} 57^{\prime} \mathrm{S}, 47^{\circ}\right.$ 50 ' $\mathrm{W}$ and altitude of $856 \mathrm{~m}$ ).

Sixteen multiparous lactating Holstein (176 DIM and $576 \mathrm{~kg}$ LBW) cows were used in the experiment. The animals were grouped according to milk production, age, body weight, body condition score and physiological state. This resulted in four homogeneous groups with four cows each, with eight cows per treatment.

The treatments were: 1) Limited time grazing of alfalfa (LGT), where the grazing time was restricted from 8 to $10 \mathrm{AM}$ and 5-7 PM, a total of 4 hours of grazing. During the remaining time (16 hours) the cows were at resting area and were fed with corn silage and concentrate; 2) Unlimited time grazing of alfalfa (UGT), where the cows had unrestricted access to the alfalfa pasture and received corn silage and concentrate.

All cows were fed with 4.5 DM $\mathrm{kg}$ of concentrate per day per cow. 10.5 and $6.6 \mathrm{DM} \mathrm{kg}$ of corn silage per cow per day for LGT and UGT, respectively, was provided. The total food was equally divided in two times (10 AM and 4 PM). Table 1 shows food and diet composition. In the resting area all animals had access to water and natural shade. Milking was done twice a day (7 AM and 7 PM).

Table 1. Chemical composition of ingredients and experimental diets (\% of DM)

\begin{tabular}{|c|c|c|c|c|c|}
\hline & $\mathrm{CP}^{1}$ & $\mathrm{NDF}^{2}$ & $\mathrm{ADF}^{3}$ & $\mathrm{LIG}^{4}$ & $\mathrm{TDN}^{5}$ \\
\hline & \multicolumn{5}{|c|}{ Concentrate } \\
\hline Corn grain & 8.4 & 9.5 & 4.2 & 1.2 & 84.4 \\
\hline Soybean meal & 50.0 & 14.9 & 8.6 & 0.9 & 80.0 \\
\hline \multirow[t]{2}{*}{ Corn silage $^{6}$} & 7.5 & 47.0 & 25.9 & 2.8 & 67.7 \\
\hline & \multicolumn{5}{|c|}{ Alfalfa } \\
\hline Whole plant & 25.0 & 37.0 & 29.0 & 5.9 & 64.0 \\
\hline \multirow[t]{2}{*}{ Plant apparently consumed $^{7}$} & 26.9 & 35.1 & 26.3 & 5.1 & 70.0 \\
\hline & \multicolumn{5}{|c|}{ Diets apparently consumed } \\
\hline Limited grazing time (4 hours) & 15.1 & 37.7 & 21.4 & 2.4 & 72.0 \\
\hline Unlimited grazing time & 19.4 & 36.0 & 21.8 & 2.9 & 72.0 \\
\hline
\end{tabular}

${ }^{1} \mathrm{CP}=$ crude protein $;{ }^{2} \mathrm{NDF}=$ neutral detergent fiber; ${ }^{3} \mathrm{ADF}=$ acid detergent fiber; ${ }^{4} \mathrm{LIG}=$ lignin $;{ }^{5} \mathrm{TDN}=$ total digestible nutrients NRC (2001); ${ }^{6} 39.0 \%$ of dry matter (DM); ${ }^{7} 20 \%$ of DM at $5 \%$ bloom.

The alfalfa pasture was rotated (every paddock was grazed for one day and rested for 30 days), irrigated and had a fixed stocking rate. For forage intake surplus, if necessary, dry cows and heifers were used in order to obtain the height of the residue between five and eight centimeters. For each treatment two repetitions were used per area, with 31 paddocks each. The area of each 
paddock per treatment was approximately 180 and $525 \mathrm{~m}^{2}$ for LGT and UGT, respectively.

The daily intake of dry matter of alfalfa was estimated weekly by the difference between the amount of available and residual forage. The determination of the quality of forage consumed was made through the grazing simulation technique where eight points per paddock were collected biweekly. Based on these samples the leaf:stem ratio was also determined. Supplied silage and concentrate samples were also taken biweekly. There was no remaining food in both treatments.

For the determination of the partially dried matter, food samples were packed in paper bags, weighed, placed in an oven with forced ventilation and maintained at $55^{\circ} \mathrm{C}$ for 72 hours. After being dried and milled, the samples were analyzed for dry matter (DM), crude protein (CP), neutral detergent fiber (NDF), acid detergent fiber (ADF) and lignin (LIG) according to the methodology described by Nogueira and Souza (2005).

The behavior of dairy cows was directly visually assessed by two trained observers and recordings were made every 10 minutes during the period from $8 \mathrm{AM}$ to 7PM, totaling 660 minutes daily. Four days of observation (October 19, 12, 23 and November 29, 2007) were conducted. The time spent on the grazing, rumination and idleness (standing or lying) activities was observed. To facilitate observation, cows were numbered with oil based paint in the back region. During the same days of behavioral observations, the bite rate in different times, at $8 \mathrm{AM}$ and 5PM, was recorded, which was obtained by directly counting the total bites observed within one minute.

The temperature and relative humidity were measured using a digital thermohygrometer. To record the black globe temperature a black globe thermometer was used. The devices were placed in the central area of the pasture at approximately $1.5 \mathrm{~m}$ above the soil and environmental variables recorded at intervals of one hour over 11 hours of observation. Based on these values the Temperature-Humidity Index (THI) (Thom,
1959) and the Black Globe-Humidity Index (BGHI) (Buffington et al., 1981) were determined.

For statistical analysis the Mixed program (SAS, 2001) was used. The model was used for the total time of grazing, rumination and idleness, as well as the bite rate, including the effects of treatment, date and the interaction between them, and the random effect of areas within and waste treatments. The mean adjusted times were compared using the Tukey test (significance level of 5\%). To analyze the time distribution of activities per treatment, the model included the fixed effects of treatment, date, time of observation and the interactions between these and the effects of random areas within the treatment, interaction between dates and areas within the treatment and waste. In the specific case of the variable grazing from the LGT treatment, the observed values from $10 \mathrm{AM}$ to 5 PM have been omitted from the analysis, since cows in this group did not have access to the pasture during this period.

\section{RESULTS AND DISCUSSION}

Meteorological variables and total time spent by cows in each activity (grazing, rumination and idleness) per evaluated day are on Table 2 . There was no rainfall in any evaluation day.

High temperature occurred on Nov 23. It reduced the time spent grazing and increased idleness (Table 2). According to Arnold and Dudzinski (1978), temperatures around $28^{\circ} \mathrm{C}$ cause thermal stress, may minimize diurnal grazing time and increase idleness time up to $77 \%$. The average temperature on Nov 23 was $28.1^{\circ} \mathrm{C}$, so it is an indicative of thermal discomfort. THI and BGHI values were 75.8 and 82.6 , respectively for Nov 23 . These indexes collaborate to confirm that the animals were in thermal stress. THI $=72$ is considered a critical value to produce milk (Pires et al., 2003). Values between 72 and 78 indicate an alert condition. BGHI values for specialized dairy cows below 74 mean comfort zone; between 74 and 78 mean alert zone; between 79 and 84 mean danger zone and above 84 mean emergency zone (Baeta, 1985). 
Table 2. Average meteorological variables and total time spent by cows in each activity per evaluation date, between $8 \mathrm{AM}$ and $7 \mathrm{PM}$

\begin{tabular}{lcccccc}
\multirow{2}{*}{ Variable } & \multicolumn{9}{c}{ Date } & & \\
\cline { 2 - 5 } & $19 / 10$ & $12 / 11$ & $23 / 11$ & $29 / 11$ & $\mathrm{SE}^{1}$ & $\mathrm{P}^{2}$ \\
\hline Minimum temperature $\left({ }^{\circ} \mathrm{C}\right)$ & 19.4 & 22.7 & 19.1 & 18.4 & - & - \\
Maximum temperature $\left({ }^{\circ} \mathrm{C}\right)$ & 29.2 & 29.6 & 35.7 & 27.0 & - & - \\
Average temperature $\left({ }^{\circ} \mathrm{C}\right)$ & 24.1 & 25.7 & 28.1 & 24.7 & - & - \\
Relative air humidity $(\%)$ & 60.4 & 68.5 & 48.3 & 35.5 & - & - \\
Temperature-Humidity Index & 72.1 & 75.3 & 75.8 & 69.6 & - & - \\
Black Globe-Humidity Index & 72.9 & 77.8 & 82.6 & 78.3 & - & - \\
Total grazing time & $204.8 \mathrm{~A}$ & $244.5 \mathrm{~A}$ & $160.9 \mathrm{~B}$ & $204.0 \mathrm{~A}$ & 8.2 & $* *$ \\
Total rumination time & $151.7 \mathrm{~A}$ & $146.3 \mathrm{~A}$ & $152.0 \mathrm{~A}$ & $139.6 \mathrm{~A}$ & 7.3 & $\mathrm{~ns}$ \\
Total idleness time & $163.3 \mathrm{~B}$ & $146.7 \mathrm{~B}$ & $218.7 \mathrm{~A}$ & $175.0 \mathrm{~B}$ & 10.3 & $* *$ \\
\hline
\end{tabular}

${ }^{\mathrm{T}}$ Standard error of mean; ${ }^{2}$ Probability of type 1 error when comparing dates.

$* * \mathrm{P}<0.01$; ns: not significant $(\mathrm{P} \geq 0.05)$.

${ }^{\mathrm{A}, \mathrm{B}}$ Means in the same column followed by different letters differ $(\mathrm{P}<0.05)$ by the Tukey test.

The total time spent by ruminants on feeding is divided between feeding and time without food (Yeates et al., 2001), which can mean rumination or idleness. Figure 1, 2 and 3 show the hourly variation for each activity per treatment.

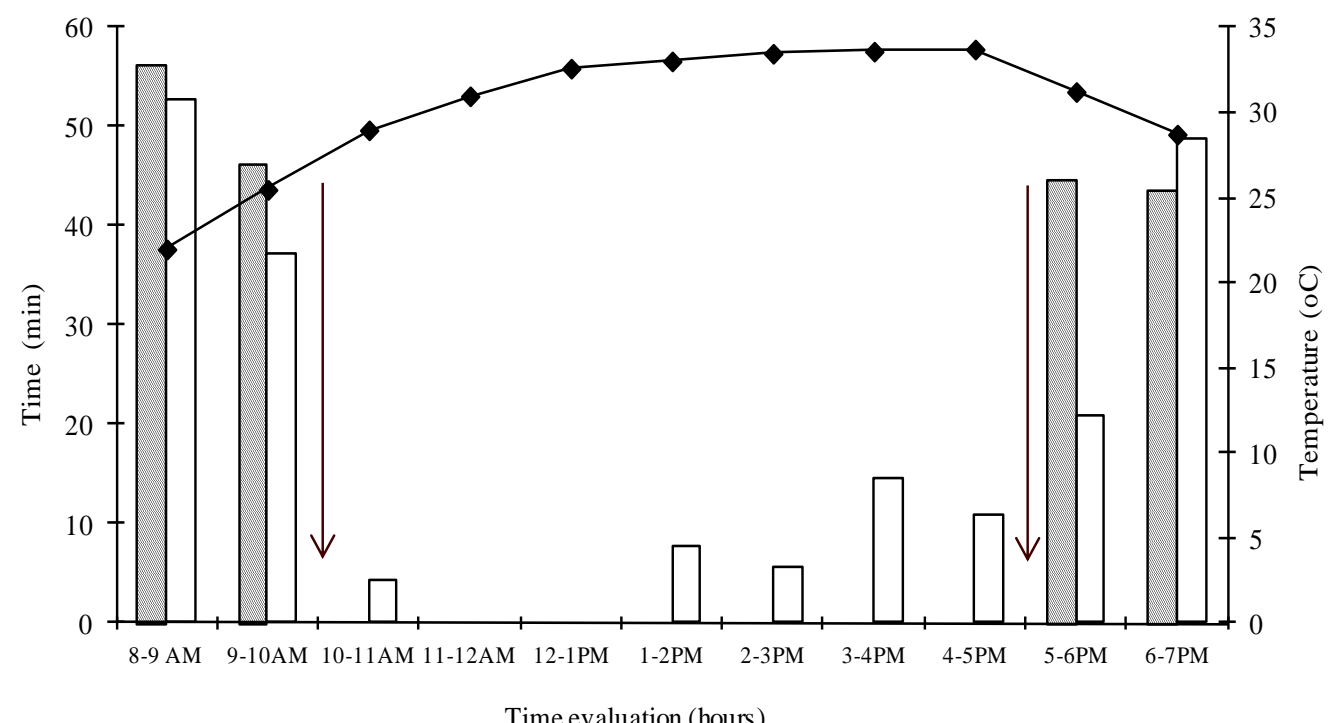

Time evaluation (hours)

$\longleftarrow$ Limited time grazing $\longleftarrow$ Unlimited time grazing $\multimap$ Black globe temperature

Figure 1. Hourly variation of black globe temperature $\left({ }^{\circ} \mathrm{C}\right)$ and time spent grazing by dairy cows on alfalfa pastures. The time between the arrows means that cows on the limited grazing treatment do not have access to pasture. 


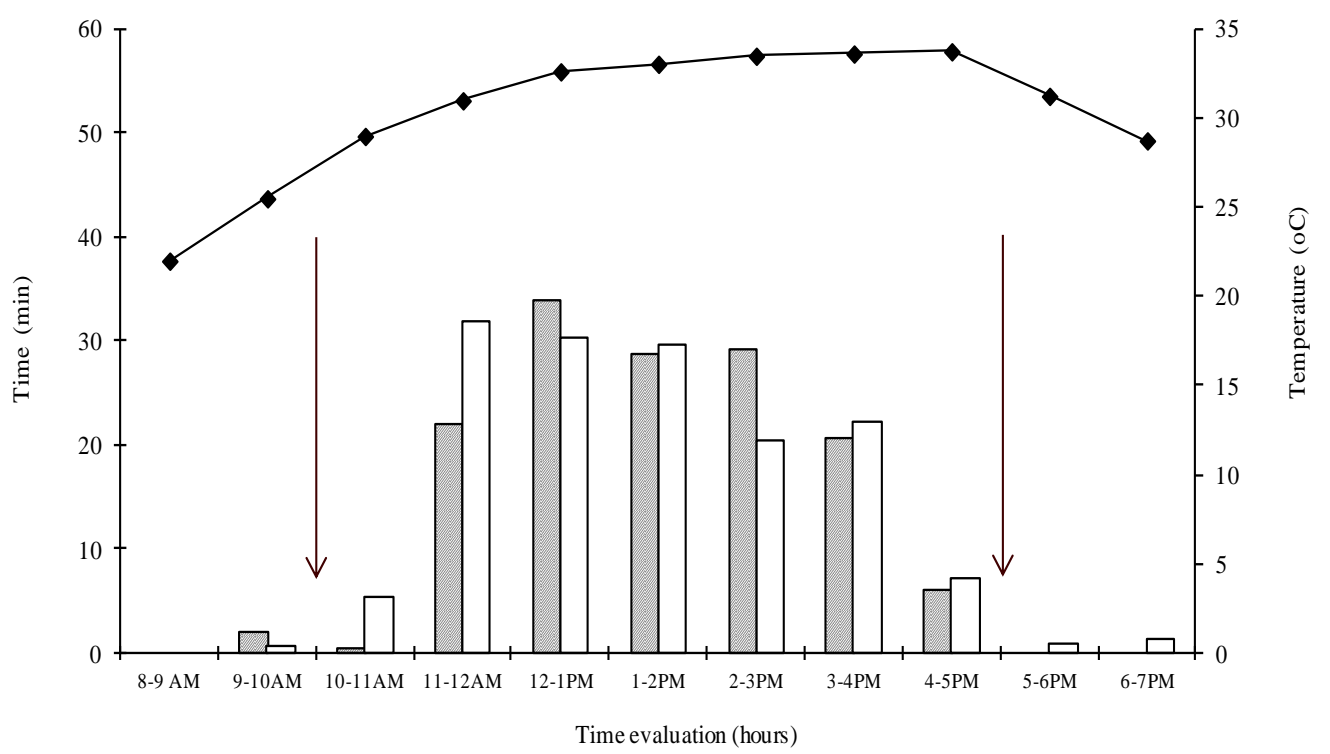

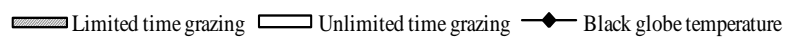

Figure 2. Hourly variation of black globe temperature $\left({ }^{\circ} \mathrm{C}\right)$ and time spent ruminating by dairy cows on alfalfa pastures. The time between the arrows means that cows in the limited grazing treatment do not have access to pasture.

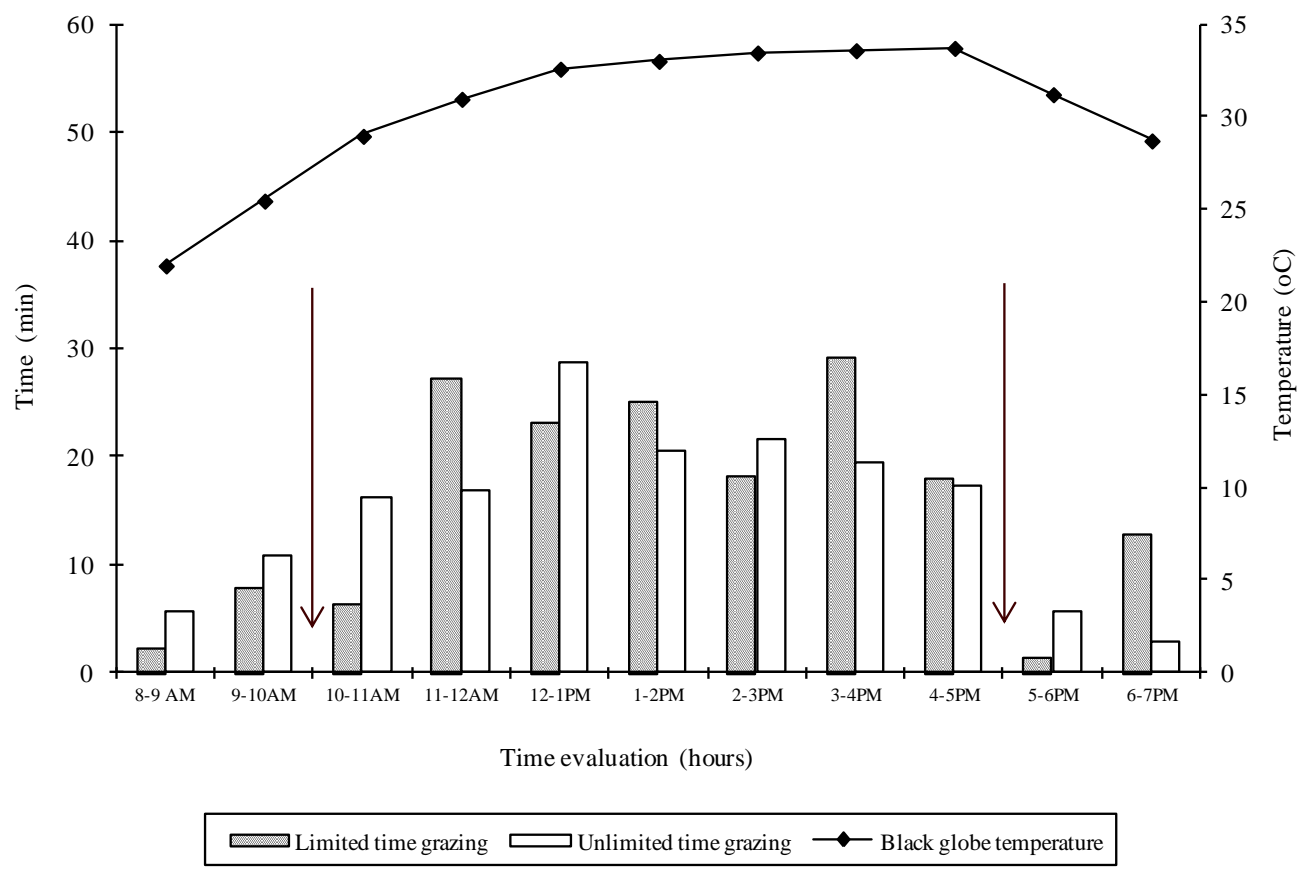

Figure 3. Hourly variation of black globe temperature $\left({ }^{\circ} \mathrm{C}\right)$ and time spent in idleness for dairy cows on alfalfa pastures. The time between the arrows means that cows on the limited grazing treatment do not have access to pasture. 
According to Hodgson (1990), in normal conditions there are 3 to 5 grazing times during the day. In this experiment 4 to 9 grazing times for LGT and UGT, respectively, were observed and they were more representative during the early morning and late afternoon (Figure 1). The variation of the grazing time in the UGT treatment between 2PM and 5PM indicates that the animals grazed intermittently for a short period, interrupted for variable periods of time, which the cows spent in other activities. It was observed that in the UGT treatment cows reduced grazing time from $10 \mathrm{AM}$ and increased rumination and idleness time (Figure 2 and 3 ). This kind of behavior suggests that environmental temperature (considered to be high among 11AM - 5PM) can influence animal behavior. Such situation leads to animals spending different times with each activity, and each one happens exclusively (Carvalho and Moraes, 2005). An increase or reduction in grazing time changes in proportion to the time spent with other activities. Furthermore, it was noticeable that the cows were conditioned to visual and audible stimulus, since they always stopped all activities and moved to the feeding trough. The time of provision of dietary supplements (10 AM and 4 PM) contributed to the change in animal behavior.

In the LGT treatment it was observed that more time was spent grazing in the morning and late afternoon (Figure 1). This suggests that the animals tried to consume more alfalfa in the available time, thus, the animals from this treatment had more grazing time than animals from the UGT treatment. Silva et al. (2009) also observed more intensive grazing during the early morning and late afternoon.

The total time spent with grazing between 8 AM to 7PM was 195.7 and 211.4 minutes for LGT and UGT, respectively. These numbers were lower than $474 \mathrm{~min}$, grazing time average related by Vilela et al., 1994 for cows grazing exclusively on alfalfa during 24 hours. Bargo et al. (2002a) observed that Holstein cows, eating a mixture of temperate grasses and supplemented with $10 \mathrm{~kg}$ of DM per cow per day of concentrate fed (mix of ground corn + corn silage + alfalfa silage + alfalfa hay), spent around 252 minutes grazing during diurnal time, values similar to this trial. Jersey heifers in an Italian ryegrass and black oats pasture supplemented with ground corn and soybean meal (total of $0.75 \%$ of live weight) spent $213 \mathrm{~min}$ grazing during the day (Pereira et al., 2005).

Alfalfa DM intake was two times bigger in UGT than in LGT. This situation was expected due to lower offers of silage and larger offers of forage (Table 3). The largest alfalfa intake in UGT can be explained by the increase of the bite rate for UGT. For this variable no differences were observed among treatments (Table 3 ).

Table 3. Average and standard error for dry matter intake, total time spent by cows in each activity, bite rate and forage offer

\begin{tabular}{|c|c|c|c|c|}
\hline \multirow{3}{*}{ Variable } & \multirow{2}{*}{\multicolumn{2}{|c|}{$\begin{array}{c}\text { Treatment } \\
\text { Alfalfa grazing }\end{array}$}} & \multirow{3}{*}{$\mathrm{SE}^{1}$} & \multirow{3}{*}{$\mathrm{P}^{2}$} \\
\hline & & & & \\
\hline & Limited & Unlimited & & \\
\hline \multicolumn{5}{|l|}{ Dry matter intake } \\
\hline Alfalfa (kg per cow per day) & $5.3^{\mathrm{B}}$ & $10.6^{\mathrm{A}}$ & 0.3 & $* *$ \\
\hline Corn silage ( $\mathrm{kg}$ per cow per day) ${ }^{3}$ & 10.5 & 6.6 & - & - \\
\hline Concentrate $\left(\mathrm{kg}\right.$ per cow per day ${ }^{3}$ & 4.5 & 4.5 & - & - \\
\hline \multicolumn{5}{|l|}{ Activity } \\
\hline Total time spent grazing (minutes) & $195.7^{\mathrm{A}}$ & $211.4^{\mathrm{A}}$ & 9.5 & ns \\
\hline Total time spent ruminating (minutes) & $142.2^{\mathrm{A}}$ & $149.7^{\mathrm{A}}$ & 8.2 & ns \\
\hline Total time spent idle (minutes) & $170.6^{\mathrm{A}}$ & $165.2^{\mathrm{A}}$ & 9.8 & ns \\
\hline Bite rate (per minute) & $34.7^{\mathrm{A}}$ & $37.1^{\mathrm{A}}$ & 2.3 & ns \\
\hline Forage offer (kg of DM per $100 \mathrm{~kg} \mathrm{BW})$ & $1.8^{\mathrm{B}}$ & $4.2^{\mathrm{A}}$ & 0.3 & $* *$ \\
\hline
\end{tabular}

${ }^{1}$ Standard error of mean; ${ }^{2}$ Probability test $\mathrm{F}: * * \mathrm{P}<0.01$; ns: not significant $(\mathrm{P} \geq 0.05)$

${ }^{3}$ Ingredients with pre-set intake.

${ }^{\mathrm{A}, \mathrm{B}}$ Means in the same column followed by different letters differ $(\mathrm{p}<0.05)$ by the Tukey test. 
According to Bargo et al. (2002b), dairy cattle that received feed supplement reduced the total time spent grazing, but the bite rate was not affected. In this trial, due to the sward structural characteristics, animals from different treatments had similar conditions to seize and gather the forage. The similarity between leaf:stem ratio among treatments (2.4 and 2.7 for LGT and UGT, respectively) corroborates this information. The bite mass is another factor that can justify the larger dry matter intake of alfalfa in the UGT treatment, since this variable is one of the most important to determine intake of grazing animals (Hodgson, 1990). For example, in a pasture with abundant supply of forage, an increase in bite mass and reduction in grazing time and/or bite rate will probably occur (Penning, 1986). For this trial the bite mass was not estimated because all grazing observations were made in a diurnal time, while all estimates for alfalfa dry matter intake were made in a 24hour period. However, forage on offer was 2.3 times bigger in UGT than in LGT (Table 3), suggesting that the largest dry matter intake on UGT occurred due to an increase in bite mass for this treatment.

A longer total time spent grazing was expected for UGT than for LGT, because animals from UGT had more nutritional demands for alfalfa and had more available time to graze, though it did not happen and UGT and LGT had similar time spent grazing. Perhaps the time spent grazing during the night (not registered in this trial) could have influenced the results. According to Rovira, 1996, 30\% of grazing activity can occur during the night.

Differences between treatments were not observed for total time spent with rumination and idleness (Table 3). According to Van Soest, 1994, time spent with rumination is related to the composition of the diet and it is proportional to cell wall content of forages. For this trial there is no evidence that dietary fiber content interfered with animal behavior. For both treatments the dietary fiber content was similar (Table 1). The similarity among treatments for rumination and idle time can be explained by the diurnal time observations, when these activities had lower occurrence. Sarmento (2003), for example, observed a higher frequency of these variables during the night. It suggests that if the cows are observed during the night, there might be differences between treatments. Vilela et al. (1994) found that with Holstein cows grazing on alfalfa 24 hours per day, the values were about 1.6 and 3.3 times larger than this trial for time spent with rumination and idleness, respectively. However, Moreno et al. (2008) evaluating Jersey heifers during the day in ryegrass (Lolium multiflorum Lam) pasture supplemented with ground corn found total time spent with rumination and idleness similar to this trial.

\section{CONCLUSION}

Restriction in grazing available time clearly influenced the distribution of time spent with grazing, rumination and idleness throughout the day. However, this effect was not observed in the total time spent in these activities.

\section{ACKOWLEDGEMENTS}

Thanks to Fapesp and Embrapa for the financial support.

\section{REFERENCES}

ARNOLD, G.W; DUDZINSKI, M.C. Ethology of free-ranging domestic animals. Amsterdan: Elsevier Science Publishers, 1978. 198p.

BAETA, F.C. Responses of lactating dairy cows to the combined effects of temperature, humidity and wind velocity in the warm season. Thesis (Ph.D.) University of Missouri, Columbia. 218pp. 1985.

BARGO, F.; MULLER, L.D.; DELAHOY, J.E. et al. Performance of high producing dairy cows with three different feeding systems combining pasture and total mixed rations. J. Dairy Sci., v.85, p.2948-2963, 2002a.

BARGO, F.P.; MULLER, L.D.; DELAHOY, J.E. et $a l$. Milk response to concentrate supplementation of high producing dairy cows grazing at two pasture allowances. J. Dairy Sci., v.85, p.1777-1792, 2002b.

BUFFINGTON, D.E.; COLLAZO-AROCHO, A.; CANTON, G.H. et al. Black globe-humidity index (BGHI) as a comfort equation for dairy cows. Transactions of the A.S.A.E, v.24, p.711-714, 1981.

CARVALHO, P.C.F.; MORAES, A. Comportamento ingestivo de ruminantes: bases para o manejo sustentável do pasto. In: CECATO, U.; JOBIM, C.C. (Org.). Manejo sustentável em pastagem. Maringá, UEM, v.1, p.1-20, 2005. 
GREGORINI, P.; EIRIN, M.; WADE, M.H. et al. The effects of a morning fasting on the evening grazing behavior and performance of strip-grazed beef heifers. The Prof.Anim. Sci., v.23, p.642-648, 2007.

GREGORINI, P.K.J.; SODER, K.J.; KENSINGER, R.S. The effects of rumen fill on short-term ingestive behavior and circulating concentrations of ghrelin, insulin and glucose of dairy cows foraging vegetative micro-swards. J. Dairy Sci., v.92, p.2095-2105, 2009a.

GREGORINI, P.; CLARK, C.E.F.; JAGO, J.G. et al. Restricting time at pasture: effects on dairy cow herbage intake, foraging behavior, hunger-related hormones, and metabolite concentration during the first grazing session. J. Dairy Sci., v.92, p.4572-4580, 2009b.

HODGSON, J. Grazing management: science into practice. New York, Longman Handbooks in Agriculture, 1990. 203pp.

JAHN, E.; VIDAL, A.; SOTO, P. Sistema de producción de leche basado en alfalfa y maíz para la zona Centro Sur. Consumo y calidad del forraje. Agric. Tec., v.60, p.99-111, 2000.

MENDONÇA, S.S.; CAMPOS, J.M.S.; VALADARES FILHO, S.C. et al. Comportamento ingestivo de vacas leiteiras alimentadas com dietas à base de cana-de-açúcar ou silagem de milho. Rev. Bras. Zootec., v.33, p.723-728, 2004.

MORENO, C.B.; FISCHER, V.; MONKS, P.L. et al. Comportamento ingestivo diurno de novilhas Jersey sob suplementação com farelo de milho em pastagem de azevém anual. Rev. Bras. Zootec., v.37, p.487-493, 2008.

NOGUEIRA, A.R.A.; SOUZA, G.B. 2005. Manual de laboratórios: solo, água, nutrição vegetal, nutrição animal e alimentos. Embrapa Pecuária Sudeste, São Carlos. 334p.

NUTRIENT requirements of dairy cattle, 7.ed. Washington: National Academy of Sciences, 2001. $381 \mathrm{p}$.

PENNING, P.D. Some effects of sward conditions on grazing behavior and intake by sheep. IN: GUIDMUNDSSON, O. (Ed.). Grazing research at northern latitudes, Proceedings..., NATO Advanced Research Workshop, Hvanneyri, Iceland. p.219-226, 1986.

PEREIRA, L.M.R.; FISCHER,V.; MORENO, C.B. et al. Comportamento ingestivo diurno de novilhas
Jersey em pastejo recebendo diferentes suplementos. Rev. Bras. Agrociência, v.11, p.453-459, 2005.

PHILLIPS, C.J.; RIND, M.I. The effects of social dominance on the production and behavior of grazing dairy cows offered forage supplements. J. Dairy Sci., v.85, p.51-59, 2001

PIRES, M.F.A; JÚNIOR, J.L.C.S; CAMPOS, A.T. et al. Zoneamento da Região Sudeste do Brasil, utilizando o índice de temperatura e umidade. Embrapa Gado de Leite, Juiz de Fora/MG, Boletim de Pesquisa e Desenvolvimento, 13. 21pp. 2003.

ROVIRA, J. Manejo nutritivo de los rodeos de cría en pastoreo. Montevideo: Hemisferio Sur, 288p. 1996.

SARMENTO, D.O.L. Comportamento ingestivo de bovinos em pastos de capim-Marandu submetidos a regimes de lotação contínua. 2003. 76p. Dissertação (Mestrado em Zootecnia) - Escola Superior de Agricultura Luiz de Queiroz, Universidade de São Paulo, Piracicaba, SP.

SILVA, E.C.M.; MODESTO, E.C.; AZEVEDO, M. et al. Efeitos da disponibilidade de sombra sobre o desempenho, atividades comportamentais e parâmetros fisiológicos de vacas da raça Pitangueiras. Acta. Sci. Anim. Sci., v.31, p.295-302, 2009.

SOUSA JÚNIOR, S.C.; MORAIS, D.A.E.F.; VASCONCELOS, A.M. et al. Características termorreguladoras de caprinos, ovinos e bovinos em diferentes épocas do ano em região semi-árida. Rev. Cient. Prod. Anim., v.10, p.127-137, 2008.

Statistical Analysis Systems User's Guide - SAS. Version 2001, SAS Institute, Cary, NC.

THOM, E.C. The discomfort index. Weatherwise, v.12, p.57-59, 1959.

VAN SOEST, P.J. Nutritional ecology of the ruminant. Ithaca: Cornell University Press, 476p. 1994.

VILELA, D.; CÓSER, A.C.; PIRES, M.F.A. et al. Comparação de um sistema de pastejo rotativo em alfafa (Medicago sativa, L.) com um sistema de confinamento para vacas de leite. Arch. Latinoam. Prod. Anim., v.2, p.69-84, 1994.

YEATES, M.P.; TOLKAMP, B.J.; ALLCROFT, D.J. et al. The use of mixed distribution models to determine bout criteria for analysis of animal behavior. J. Theor. Biol., v.213, p.413-425, 2001. 